in vivo $34: 1117-1123(2020)$

doi:10.21873/invivo.11883

\title{
Significant Association of Interleukin-16 Genetic Variations to Taiwanese Lung Cancer
}

\author{
MENG-FENG WU ${ }^{1,2,3^{*}}$, YUN-CHI WANG $^{1,2^{*}}$, TE-CHUN SHEN $^{1,2^{*}}$, WEN-SHIN CHANG $^{1,2}$, \\ HSIN-TING LI ${ }^{2}$, CHENG-HSI LIAO ${ }^{1,2}$, CHI-LI GONG ${ }^{2}$, ZHI-HONG WANG $^{4}$, \\ CHIA-WEN TSAI ${ }^{1,2}$, TE-CHUN HSIA ${ }^{2,5,6}$ and DA-TIAN BAU ${ }^{1,2,7}$ \\ ${ }^{1}$ Graduate Institute of Biomedical Sciences, China Medical University, Taichung, Taiwan, R.O.C.; \\ ${ }^{2}$ Terry Fox Cancer Research Laboratory, Department of Medical Research, \\ China Medical University Hospital, Taichung, Taiwan, R.O.C.; \\ ${ }^{3}$ Division of Chest Surgery, Department of Surgery, \\ Taoyuan Armed Forces General Hospital, Taoyuan, Taiwan, R.O.C.; \\ ${ }^{4}$ Department of Food Nutrition and Health Biotechnology, Asia University, Taichung, Taiwan, R.O.C.; \\ ${ }^{5}$ Department of Respiratory Therapy, China Medical University, Taichung, Taiwan, R.O.C.; \\ ${ }^{6}$ Department of Internal Medicine, China Medical University Hospital, Taichung, Taiwan, R.O.C.; \\ ${ }^{7}$ Department of Bioinformatics and Medical Engineering, Asia University, Taichung, Taiwan, R.O.C.
}

\begin{abstract}
Background/Aim: Interleukin-16 has been reported to exhibit tumoricidal effects, however, the contribution of IL-16 genotypes to lung cancer is still largely unrevealed. This study aimed at investigating whether IL-16 genotypes contribute to lung cancer susceptibility. Materials and Methods: IL-16 rs4778889, rs 11556218, and rs4072111 genotypic characteristics were determined among 358 lung cancer patients and 716 controls via the polymerase chain reaction-based restriction fragment length polymorphism (PCR-RFLP) methodology. Results: The highlight finding is that the distributions of genotypic $(p=8.6 E-10)$ and allelic $(p=0.0001)$ frequencies of IL-16 rs11556218 was significantly different between cases and controls. In detail, the frequencies of IL-16 rs11556218 heterozygous variant
\end{abstract}

This article is freely accessible online.

*These Authors contribute equally to this study.

Correspondence to: Da-Tian Bau and Te-Chun Hsia, Terry Fox Cancer Research Laboratory, Department of Medical Research, China Medical University Hospital, 2 Yuh-Der Road, Taichung, 404 Taiwan, R.O.C. Tel: +886 422053366 ext. 5805, e-mail: datian@mail.cmuh.org.tw (D-T Bau) and Chia-Wen Tsai, Terry Fox Cancer Research Laboratory, Department of Medical Research, China Medical University Hospital, 2 Yuh-Der Road, Taichung, 404 Taiwan, R.O.C. Tel: +886 422053366 ext. 5805, e-mail: artbau2@gmail.com

Key Words: Genotype, interleukin-16, lung cancer, single nucleotide polymorphism.
$T G$ and homozygous variant GG were 36.6 and $7.3 \%$ among the lung cancer patients, significantly higher than those among the controls (22.5\% and 2.6\%). On the other way, no difference was observed regarding $I L-16$ rs4778889 or $I L$ 16 rs4072111. Conclusion: The present study indicates IL-16 rs11556218 G allele is significantly associated with increased Taiwan lung cancer risk.

Lung cancer remains a serious public health problem since it has been the leading cause of cancer mortality worldwide $(1,2)$. Although first-line chemotherapeutic approaches such as paclitaxel (PTX) and cisplatin (CDDP) doublet chemotherapy are effective for non-small cell lung cancer (NSCLC) and small cell lung cancer (SCLC) (3-5), the 5year survival rates are still very low (6-8). Thus, a better target or marker for advanced precise therapeutic approaches such as immunotherapy is urgently needed. To fulfill this aim, several groups have reported that specific genotypes are associated with increased lung cancer risk for cigarette smokers than non-smokers (9-16) and vice versa (17-20) from genomic investigations. These studies elucidating the contribution of both genomic and behavioral factors to lung cancer etiology may provide better therapeutic decisionmaking consulting systems for revealing the personalized etiology, precision therapy and genomic pharmacology of lung cancer.

Interleukin-16 (IL-16), a cytokine originally described as lymphocyte chemoattractant factor (LCF) in 1982 (21), is encoded by the $I L-16$ gene located on chromosome $15 \mathrm{q} 26.3$. It is composed of 631 amino acids and further cleaved by caspase 3 to active IL-16 comprising the C-terminal 121 
in vivo $34: 1117-1123(2020)$

Table I. Cistribution of demographic data of 358 lung cancer patients and 716 matched non-cancer controls.

\begin{tabular}{|c|c|c|c|c|c|c|c|}
\hline \multirow[t]{2}{*}{ Characteristics } & \multicolumn{3}{|c|}{ Controls $(\mathrm{n}=716)$} & \multicolumn{3}{|c|}{ Patients $(n=358)$} & \multirow[t]{2}{*}{$p$-Value } \\
\hline & $\mathrm{N}$ & $\%$ & Mean (SD) & $\mathrm{N}$ & $\%$ & Mean (SD) & \\
\hline Age (years) & & & $64.8(6.8)$ & & & $64.0(6.9)$ & 0.5871 \\
\hline \multicolumn{8}{|l|}{ Gender } \\
\hline Male & 488 & $68.1 \%$ & & 254 & $70.9 \%$ & & \\
\hline Female & 228 & $31.9 \%$ & & 104 & $29.1 \%$ & & 0.3642 \\
\hline \multicolumn{8}{|l|}{ Smoking status } \\
\hline Ever smokers & 563 & $78.6 \%$ & & 293 & $81.8 \%$ & & \\
\hline Non-smokers & 153 & $21.4 \%$ & & 65 & $18.2 \%$ & & 0.2282 \\
\hline \multicolumn{8}{|l|}{ Histology } \\
\hline Adenocarcinoma & & & & 218 & $60.9 \%$ & & \\
\hline SCC & & & & 106 & $29.6 \%$ & & \\
\hline Other & & & & 34 & $9.5 \%$ & & \\
\hline
\end{tabular}

aBased on Chi-square test. SCC, Squamous cell carcinoma; SD, standard deviation.

amino acids (22-24). Binding together with CD4 protein, IL16 is capable to activate $\mathrm{CD} 4+\mathrm{T}$ cells, monocytes, macrophages, eosinophils, and dendritic cells, and promote their secretion of inflammatory cytokines, such as IL-1b (25), TNF-a, and IL-15 (26). Interestingly, elevated IL-16 levels were observed in several types of cancer tissues both in vitro and in vivo (27-33). Recently, a genome-wide association study reported that $I L-16$ genotype may be capable to serve as a practical marker for prostate cancer prediction (34). One study indicated that IL-16 rs11556218 T/G was significantly associated with the risk of colorectal cancer and gastric cancer patients (33). In the same study, both male and female patients carrying the $G$ allele had a significantly higher risk for developing colorectal cancer and gastric cancer compared to $\mathrm{T}$ allele carriers. Alternatively, women carrying the $\mathrm{T}$ allele at $I L-16$ rs4072111 have a lower risk for colorectal cancer and gastric cancer compared than those carrying the $\mathrm{C}$ allele (33).

Despite the significance of $I L-16$ in cancer pathogenesis, no investigation of the association between $I L-16$ genotypes and lung cancer has been studied. Based on the highlights above, we aimed at evaluating whether rs4778889 $\mathrm{T} / \mathrm{C}$, rs11556218 T/G and rs4072111 C/T polymorphisms of $I L$ 16 are associated with the personal risk to lung cancer in a representative Taiwan population. In addition, the joint effect of smoking status and $I L-16$ genotypes on lung cancer risk is also examined.

\section{Materials and Methods}

Investigated controls and cases. Briefly, three hundred and fiftyeight lung cancer patients were recruited at the China Medical University Hospital in central Taiwan. The demographic indexes of the lung cancer patients, including their histological details, were all graded and defined by expert surgeons led by Dr. Hsia. First, patients with lung cancer history of any other cancer and pulmonary diseases, such as chronic obstructive pulmonary disease (COPD), pneumothorax and asthma, were all excluded. Then, the participants, who were all Taiwanese, were asked to complete a self-administered questionnaire and provide their blood sample for genotyping studies after their agreeing to join this project. Second, twice the number of non-lung cancer healthy volunteers, as controls, were selected by a criterion matching for age, gender and smoking status after an initially random sampling from the Health Examination Cohort of the hospital. Third, the exclusion criteria for the controls included previous malignancy, metastasized cancer from other origin(s), and any well-known genetic or familial diseases. The study has been reviewed and approved by the Institutional Review Board with the document coded DMR100-IRB-284 and the written informed consents were collected from all the subjects in this project. The demographic characteristics such as the age, gender, smoking status and histological types are shown in Table I.

IL-16 genotyping conditions. Genomic DNA from the peripheral blood leucocytes of each lung cancer patient and control subject was prepared using the QIAamp Blood Mini Kit (Blossom, Taipei, Taiwan) $(35,36)$ and further processed in a typical polymerase chain reaction (PCR) processes as our previous papers (37-39). The designed primer sequences, corresponding restriction enzymes (New England BioLabs, Ipswich, MA, USA) and PCR products after enzyme digestion for $I L-16$ genotyping identification are shown in Table II. The PCR cycling were set as: one cycle at $94^{\circ} \mathrm{C}$ for $5 \mathrm{~min}$; 35 cycles of $94^{\circ} \mathrm{C}$ for $30 \mathrm{~s}, 55^{\circ} \mathrm{C}$ for $30 \mathrm{~s}$, and $72^{\circ} \mathrm{C}$ for $30 \mathrm{~s}$; and a final extension at $72^{\circ} \mathrm{C}$ for $10 \mathrm{~min}$. The agarose gel is $3 \%$ and the electrophoresis conditions are 100 Volt for $20 \mathrm{~min}$. The genotyping analysis was conducted by three researchers independently and blindly. For each of the $I L-16$ SNP investigated in this study, 18 of the cases and 36 of the controls were chosen for direct sequencing. Overall, the genotypes identified by PCR-based RFLP methodology and direct sequencing methodology were one hundred percent concordant to each other.

Statistical analyses. Seven hundred and sixteen of the controls and 358 lung cancer patients with both genotypic and selected characters listed in Table I were analyzed. The Student's $t$-test was used to 
Wu et al: $I L-16$ Genotypes in Lung Cancer

Table II. Sequences of the primers, restriction enzymes and fragment identifications for IL-16 rs4778889, rs11556218 and rs4072111 genotyping.

\begin{tabular}{|c|c|c|c|}
\hline Polymorphism & 5 ' to 3' primer sequences & Restriction enzymes & Allelic type and product size (bp) \\
\hline \multirow[t]{2}{*}{ rs4778889 } & CTCCACACTCAAAGCCСТTT & Ahd $\mathrm{I}$ & T: 280 \\
\hline & CCATGTCAAAACGGTAGCCT & & C: $246+34$ \\
\hline \multirow[t]{2}{*}{ rs 11556218} & GCTCAGGTTCACAGAGTGTT & Nde I & G: 171 \\
\hline & TGTGACAATCACAGCTTGCC & & $\mathrm{T}: 147+24$ \\
\hline \multirow[t]{2}{*}{ rs4072111 } & CACTGTGATCCCGGTCCAGT & BsmA I & C: 164 \\
\hline & TTCAGGTACAAACCCAGCCA & & $\mathrm{T}: 140+24$ \\
\hline
\end{tabular}

compare the difference of age between the case and control groups. Typical Pearson's Chi-square test was adopted for comparisons of the distributions for the $I L-16$ genotypes between the case and control groups. The associations between the $I L-16$ genotypes and lung cancer risk were estimated by computing odds ratios (ORs) and their $95 \%$ confidence intervals (CIs) from logistic regression analysis. Any comparison with $p<0.05$ was considered statistically significant.

\section{Results}

Table I summarizes the demographic characteristics of the 1,074 participants (358 patients with lung cancer and 716 non-cancer healthy controls) in this study. No significant difference on age, gender distribution or smoking and alcohol consumption status was identified between lung cancer and control groups, suggesting that subject matching based on these indexes was successful as we have designed. From the viewpoints of pathological identification, there were $60.9 \%$ of lung cancer patients belonging to the adenocarcinoma type, $29.6 \%$ of the lung cancer patients belonging to the squamous cell carcinoma type, and $9.5 \%$ belonging to other types (Table I).

In Table III, we summarize the distribution of genotypic frequencies of the 3 SNPs (rs4778889, rs11556218 and rs4072111 in $I L-16$ ) for all the investigated subjects. First, we investigated the genotypic frequencies for the three SNPs agreed with the Hardy-Weinberg equilibrium in the control group (all $p>0.05$ ). Second, noticeably, there is a significant difference in the distribution of $I L-16$ rs11556218 genotypic frequencies between lung cancer and control groups ( $p$ for trend=8.6E-10) (Table III, middle panel), but not for those of $I L-16$ rs4778889 or $I L-16$ rs4072111 (both $p$ for trend $>0.05$ ) (Table III, top and bottom panels). In detail, the frequencies of the $I L-16$ rs11556218 heterozygous variant TG and homozygous variant GG were 36.6 and $7.3 \%$ among lung cancer patients, are significantly higher compared to those among the healthy controls $(22.5 \%$ and $2.6 \%)$. Thus, the TG $(\mathrm{OR}=2.17,95 \% \mathrm{CI}=1.64-2.88, p=0.0001)$ and $\mathrm{GG}$ $(\mathrm{OR}=3.65,95 \% \mathrm{CI}=1.98-6.74, p=0.0001)$ genotype at $I L-16$ rs11556218 seemed to be a potential biomarker for higher risk of Taiwan lung cancer. Last, we combined the variant TG+GG at $I L-16$ rs11556218, and examined if the elevated risk for lung cancer risk still exists in this combined genotypes compared with wild-type TT genotype ( $\mathrm{OR}=2.33$, 95\% CI=1.78-3.04, $p=0.0001$ ) (Table III, middle panel).

The distribution of allelic frequencies of the 3 SNPs in $I L$ 16 are analyzed to validate the findings in Table IV. Consistent with the findings in Table III, the variant $G$ allele at $I L-16$ rs 11556218 was associated with a significantly elevated risk of lung cancer, compared to the wild-type allele $\mathrm{T}(\mathrm{OR}=2.13,95 \% \mathrm{CI}=1.70-2.66, p=0.0001)$ (Table IV, middle panel). In detail, the frequencies of the $\mathrm{T}$ and $\mathrm{G}$ alleles of $I L$ 16 rs 11556218 were $74.4 \%$ and $25.6 \%$ among lung cancer patients, respectively, while are $86.1 \%$ and $13.9 \%$ among the healthy controls (Table IV, middle panel). On the contrary, neither the variant $\mathrm{C}$ allele of $I L-16$ rs4778889 nor variant $\mathrm{T}$ allele of $I L-16$ rs4072111 was associated with lung cancer risk (Table IV, top and bottom parts).

Since lung cancer is one of the smoking behavior-related cancers, we also examined the interaction between the genotype of $I L-16$ rs11556218 with personal smoking behavior among the investigated subjects. The joint effects of $I L-16$ rs11556218 genotype with individual smoking status are shown in Table V. The lung cancer patients and matched controls were stratified according to their smoking status. The results showed that there was also a significantly elevated lung cancer risk for those non-smokers with variant TG or GG genotypes at $I L-16$ rs11556218 $(p=0.0022)$ (Table $\mathrm{V}$, top panel). At the same time, ever smokers carrying variant TG and GG genotypes at $I L-16$ rs 11556218 were at an increased risk of lung cancer $(p=2.8 \mathrm{E}-7)$ (Table $\mathrm{V}$, bottom panel). There is no joint effect between rs4778889 or $I L-16$ rs4072111 with smoking on lung cancer risk determination (data not shown).

\section{Discussion}

In the current study, we investigated the association of $I L-16$ genotypes and lung cancer risk in a moderate population of Taiwanese, containing 358 lung cancer patients and 716 age-, gender- and behavior-matched healthy controls (Table I). The results from PCR-RFLP showed that $I L-16$ rs $11556218 \mathrm{G}$ carriers were of a statistically higher risk for lung cancer 
Table III. Distribution of IL-16 rs4778889, rs 11556218 and rs4072111 genotypes among the 358 lung cancer and the 716 controls.

\begin{tabular}{|c|c|c|c|c|c|c|}
\hline \multirow[t]{2}{*}{ Genotype } & \multicolumn{2}{|c|}{ Cases } & \multicolumn{2}{|c|}{ Controls } & \multirow[t]{2}{*}{ OR (95\% CI) } & \multirow[t]{2}{*}{$p$-Value ${ }^{\mathrm{a}}$} \\
\hline & $\mathrm{N}$ & $\%$ & $\mathrm{~N}$ & $\%$ & & \\
\hline \multicolumn{7}{|l|}{ rs4778889 } \\
\hline $\mathrm{TT}$ & 234 & $65.4 \%$ & 456 & $63.7 \%$ & 1.00 (reference) & \\
\hline $\mathrm{CT}$ & 113 & $31.5 \%$ & 239 & $33.4 \%$ & $0.92(0.70-1.21)$ & 0.5575 \\
\hline $\mathrm{CC}$ & 11 & $3.1 \%$ & 21 & $2.9 \%$ & $1.02(0.48-2.15)$ & 0.9570 \\
\hline $\mathrm{CT}+\mathrm{CC}$ & 124 & $34.6 \%$ & 260 & $36.3 \%$ & $0.93(0.71-1.21)$ & 0.5890 \\
\hline $\begin{array}{l}P_{\text {trend }} \\
\text { rs } 11556218\end{array}$ & & & & & & 0.8353 \\
\hline $\mathrm{TT}$ & 201 & $56.1 \%$ & 536 & $74.9 \%$ & 1.00 (reference) & \\
\hline TG & 131 & $36.6 \%$ & 161 & $22.5 \%$ & $2.17(1.64-2.88)$ & 0.0001* \\
\hline GG & 26 & $7.3 \%$ & 19 & $2.6 \%$ & $3.65(1.98-6.74)$ & $0.0001 *$ \\
\hline $\mathrm{TG}+\mathrm{GG}$ & 157 & $43.9 \%$ & 180 & $25.1 \%$ & $2.33(1.78-3.04)$ & 0.0001* \\
\hline $\begin{array}{l}P_{\text {trend }} \\
\text { rs } 4072111\end{array}$ & & & & & & 8.6E-10* \\
\hline $\mathrm{CC}$ & 224 & $62.6 \%$ & 441 & $61.6 \%$ & 1.00 (reference) & \\
\hline $\mathrm{CT}$ & 117 & $32.7 \%$ & 247 & $34.5 \%$ & $0.93(0.71-1.22)$ & 0.6155 \\
\hline TT & 17 & $4.7 \%$ & 28 & $3.9 \%$ & $1.20(0.64-2.23)$ & 0.5746 \\
\hline $\mathrm{CT}+\mathrm{TT}$ & 134 & $37.4 \%$ & 275 & $38.4 \%$ & $0.96(0.74-1.25)$ & 0.7558 \\
\hline$P_{\text {trend }}$ & & & & & & 0.7157 \\
\hline
\end{tabular}

aBased on Chi-square without Yate's correction test; significant $p$-values and odds ratios are bolded and marked with an asterisk $(*)$.

(Tables III and IV). Thus, IL-16 rs11556218 TG and GG genotypes, but not any genotype at $I L-16$ rs4778889 or $I L$ 16 rs4072111 (Table III), were novel genomic biomarkers for prediction of elevated lung cancer risk in Taiwan. We further found that variant genotypes of $I L-16$ rs 11556218 were associated with elevated lung cancer risk among not only non-smoker but smoker subgroups (Tables V). These findings support the concept that functional polymorphisms of $I L-16$ involve in the lung cancer etiology.

The first SNP rs4778889 is an intronic polymorphic site, whose variations seemed not to contribute to altered lung cancer risk from the results (Tables III and IV). The third SNP rs4072111 is a polymorphic site in charge of a missense coding from wild-type Pro (C) to variant Ser (T), whose genetic variations seem not to contribute to altered lung cancer risk (Tables III and IV). The highlight findings focus on the second SNP rs11556218 we checked, which is also a polymorphic site in charge of a missense coding from wildtype Asn $(\mathrm{T})$ to variant Lys $(\mathrm{G})$. The results show that the variant $\mathrm{G}$ allele at $I L-16$ rs 11556218 was associated with a significantly elevated risk of lung cancer, compared to the wild-type allele $\mathrm{T}$ (Table IV). In the literature, serum levels of $I L-16$ were reported to be higher in colorectal cancer and gastric cancer patients (33). However, no significant genotype-phenotype correlation between $I L-16$ rs 11556218 polymorphisms and serum levels of IL-16 was observed in that study (33).
Table IV. Distribution of IL-16 rs4778889, rs 11556218 and rs 4072111 allelic frequencies among the 358 lung cancer and the 716 controls.

\begin{tabular}{lrrrrrr}
\hline Allele & Cases & $\%$ & Controls & $\%$ & OR (95\% CI) & $p$-Value \\
\hline rs4778889 & & & & & & \\
Allele T & 581 & $81.1 \%$ & 1251 & $80.4 \%$ & 1.00 (reference) & \\
Allele C & 135 & $18.9 \%$ & 281 & $19.6 \%$ & $1.03(0.82-1.30)$ & 0.7706 \\
rs11556218 & & & & & & \\
Allele T & 533 & $74.4 \%$ & 1233 & $86.1 \%$ & 1.00 (reference) & \\
Allele G & 183 & $25.6 \%$ & 199 & $13.9 \%$ & $\mathbf{2 . 1 3}(\mathbf{1 . 7 0 - 2 . 6 6 )}$ & $\mathbf{0 . 0 0 0 1 *}$ \\
rs4072111 & & & & & & \\
Allele C & 565 & $78.9 \%$ & 1229 & $78.8 \%$ & 1.00 (reference) & \\
Allele T & 151 & $21.1 \%$ & 303 & $21.2 \%$ & $1.08(0.87-1.35)$ & 0.4706 \\
\hline
\end{tabular}

aBased on Chi-square without Yate's correction test; the significant $p$ value and odds ratio are bolded and marked with an asterisk (*).

Table V. Distribution of IL-16 rs11556218 genotypes among 358 lung cancer and 716 controls after stratification by smoking status.

\begin{tabular}{lcccr}
\hline $\begin{array}{l}\text { Behavior } \\
\text { group }\end{array}$ & \multicolumn{2}{c}{$I L-16$ rs11556218 genotype } & \\
\cline { 2 - 3 } & TT (\%) & TG (\%) & GG (\%) & $p$-Value \\
\hline $\begin{array}{l}\text { Non-smokers } \\
\quad \text { Controls }\end{array}$ & $116(75.8 \%)$ & $32(20.9 \%)$ & $5(3.3 \%)$ & \\
$\quad$ Cases & $34(52.3 \%)$ & $25(38.5 \%)$ & $6(9.2 \%)$ & $\mathbf{0 . 0 0 2 2} *$ \\
$\begin{array}{l}\text { Smokers } \\
\quad \text { Controls }\end{array}$ & $420(74.6 \%)$ & $129(22.9 \%)$ & $14(2.5 \%)$ & \\
$\quad$ Cases & $167(57.0 \%)$ & $106(36.2 \%)$ & $20(6.8 \%)$ & $\mathbf{2 . 8 E - 7 *}$ \\
\hline
\end{tabular}

aBased on Chi-square without Yate's correction test; the significant $p$ values are bolded and marked with an asterisk $(*)$.

In the current study, we proposed a practical biomarker, the TG and GG genotypes at $I L-16$ rs11556218, for lung cancer prediction in Taiwan (Tables III and IV). The elevated risk was also found in several types of cancers including gastric cancer (33), colorectal cancer (33), HBV-related hepatocellular carcinoma (40) and nasopharyngeal carcinoma (41).

The genotype of $I L-16$ rs4778889 was found to be associated with the risk of renal cell carcinoma (42). In the most updated meta-analysis of $I L-16$ genotype and cancer, the $\mathrm{C}$ allele at $I L-16$ rs 4778889 was found to significantly correlate with higher renal cell carcinoma risk, especially among Asian ethnicities (43). Different from those findings mentioned above, genotypes of $I L-16$ rs 11556218 were not associated with the risk of the risk of renal cell carcinoma, and the mechanisms need further validation.

Since lung cancer is one of the smoking-related cancers, the interaction of the genotype of $I L-16$ rs 11556218 and cigarette smoking status for the participants is further analyzed after we have revealed its contribution to lung 
cancer susceptibility in Table V. The results showed that the genotypic distribution of the variant genotypes of $I L-16$ rs11556218 was significantly different between lung cancer and control sub-groups both with and without the cigarette smoking habits (Table V). At the same time, there is no differential distribution observed for the genotypes of $I L-16$ rs4778889 nor rs4072111 among neither smokers nor nonsmokers (data not shown). As for the gender difference, Gao and colleagues reported that both male and female patients carrying the $G$ allele had a significantly higher risk for developing colorectal cancer and gastric cancer compared to individuals carrying the $\mathrm{T}$ allele (33). Their findings are similar to ours that no gender difference on the significance for IL-16 rs11556218 genotypes was observed. We also analyzed the interaction of the $I L-16$ rs11556218 genotype with age and alcohol drinking status finding that the interactions were significant both among younger and elderly groups, and also both in drinker and non-drinker groups (data not shown). Thus, the marker $I L-16$ rs 11556218 is practically useful for lung cancer prediction among Taiwanese for both genders, and for those with or without smoking or alcohol drinking habits.

From the pathobiological viewpoint, the elevated levels of serum IL-16 have been found in metastatic cancers and correlated with poorer prognosis of several types of cancer including breast cancer, gastrointestinal cancer, renal cancer, ovarian cancer and myeloma $(44,45)$. Those SNPs on $I L-16$ such as rs 11556218 have been reported to associate with risk to gastric cancer (46), colorectal cancer (46), prostate cancer (47) and renal cancer (48). Donati and colleagues demonstrated that IL-16 plays a role in early steps of lung cancer cell metastasis (49). In 2017, Pérez-Ramírez and colleagues reported that the variant GG genotypes at $I L-16$ rs 7170924 could serve as a predictive marker for higher risk of death (50). In the current study, neither $I L-16$ rs11556218, rs4778889 nor rs4072111 could serve as a predictive marker for poorer prognosis of lung cancer in the aspects of metastasis or death risk (data not shown).

In conclusion, this study provides evidence that the TG and GG genotypes of $I L-16$ rs 11556218 are associated with increased lung cancer risk among Taiwanese, no matter whether being with or without a personal smoking habit. Further studies with larger subject numbers from diverse ethnic populations are needed to verify our findings, in which potential gene-gene and gene-environmental interactions on lung cancer risk validations would be very valuable.

\section{Conflicts of Interest}

All the Authors declare no conflicts of interest regarding this study.

\section{Authors' Contributions}

Research design: Wu MF, Tsai $\mathrm{CW}$; patient and questionnaire summaries: Shen TC, Hsia TC; experimental work: Wang YC, Chang WS, Li HT; statistical analysis: Liao CH, Gong CL, Wang $\mathrm{ZH}$; manuscript writing: Tsai CW, Bau DT; review \& revision: Bau DT, Chang WS, Tsai CW.

\section{Acknowledgements}

The Authors are grateful to the Tissue-bank of China Medical University Hospital and doctors/nurses under Prof. Hsia's leadership for their excellent sample collection and technical assistance. The technical assistance from Yu-Ting Chin, Tai-Lin Huang, Yu-Hsin Lin, Yi-Ru Huang and Yu-Chen Hsiau, the consultants of statistical analysis from Cheng-Li Lin are very helpful in manuscript preparation. This study was supported by research grants from China Medical University Hospital and Asia University (CMU108ASIA-02) and from Taiwan Ministry of Science and Technology (MOST 106-2314-B-039-022) to Dr. Hsia.

\section{References}

1 Siegel RL, Miller KD and Jemal A: Cancer statistics, 2015. CA Cancer J Clin 65: 5-29, 2015. PMID: 25559415. DOI: $10.3322 / \mathrm{caac} .21254$

2 Torre LA, Bray F, Siegel RL, Ferlay J, Lortet-Tieulent J and Jemal A: Global cancer statistics, 2012. CA Cancer J Clin 65: 87-108, 2015. PMID: 25651787. DOI: 10.3322/caac.21262

3 Dimitroulis J, Rapti A, Stathopoulos GP, Rigatos S, Stathopoulos J, Koutantos J, Athanasiadis A, Tsikritsaki K, Karaindros D, Katis $\mathrm{K}$, Antoniou $\mathrm{D}$, Toumbis $\mathrm{M}$ and Giamboudakis $\mathrm{P}$ : Comparison of cisplatin-paclitaxel combination versus cisplatinetoposide in patients with small-cell lung cancer: a phase III study. Oncol Rep 20: 879-884, 2008. PMID: 18813830. DOI: 10.3892/or_00000086

4 Gupta N, Hatoum H and Dy GK: First line treatment of advanced non-small-cell lung cancer - specific focus on albumin bound paclitaxel. Int J Nanomedicine 9: 209-221, 2014. PMID: 24399877. DOI: $10.2147 /$ IJN.S41770

5 Rossi A, Chiodini P, Sun JM, O’Brien ME, von Plessen C, Barata F, Park K, Popat S, Bergman B, Parente B, Gallo C, Gridelli C, Perrone F and Di Maio M: Six versus fewer planned cycles of first-line platinum-based chemotherapy for non-smallcell lung cancer: a systematic review and meta-analysis of individual patient data. Lancet Oncol 15: 1254-1262, 2014. PMID: 25232001. DOI: 10.1016/S1470-2045(14)70402-4

6 Li Z, Chen L and Qin Z: Paradoxical roles of IL-4 in tumor immunity. Cell Mol Immunol 6: 415-422, 2009. PMID: 20003817. DOI: $10.1038 / \mathrm{cmi} .2009 .53$

7 Liew MS, Sia J, Starmans MH, Tafreshi A, Harris S, Feigen M, White S, Zimet A, Lambin P, Boutros PC, Mitchell P and John $\mathrm{T}$ : Comparison of toxicity and outcomes of concurrent radiotherapy with carboplatin/paclitaxel or cisplatin/etoposide in stage III non-small cell lung cancer. Cancer Med 2: 916-924, 2013. PMID: 24403265. DOI: $10.1002 /$ cam 4.142

8 Spiro SG and Silvestri GA: One hundred years of lung cancer. Am J Respir Crit Care Med 172: 523-529, 2005. PMID: 15961694. DOI: $10.1164 / \mathrm{rccm} .200504-531 \mathrm{OE}$ 
9 Ji YN, Wang Q and Suo LJ: CYP1A1 Ile462Val polymorphism contributes to lung cancer susceptibility among lung squamous carcinoma and smokers: a meta-analysis. PLoS One 7: e43397, 2012. PMID: 22952673. DOI: 10.1371/journal.pone.0043397

10 Spitz MR, Gorlov IP, Dong Q, Wu X, Chen W, Chang DW, Etzel CJ, Caporaso NE, Zhao Y, Christiani DC, Brennan P, Albanes D, Shi J, Thun M, Landi MT and Amos CI: Multistage analysis of variants in the inflammation pathway and lung cancer risk in smokers. Cancer Epidemiol Biomarkers Prev 21: 1213-1221, 2012. PMID: 22573796 DOI: 10.1158/1055-9965.EPI-12-0352-T

11 Hsia TC, Chang WS, Liang SJ, Chen WC, Tu CY, Chen HJ, Yang MD, Tsai CW, Hsu CM, Tsai CH and Bau DT: Interleukin10 (IL-10) promoter genotypes are associated with lung cancer risk in Taiwan males and smokers. Anticancer Res 34: 70397044, 2014. PMID: 25503130.

12 Hsia TC, Chang WS, Chen WC, Liang SJ, Tu CY, Chen HJ, Liang JA, Tsai CW, Hsu CM, Tsai CH and Bau DT: Genotype of DNA double-strand break repair gene XRCC7 is associated with lung cancer risk in Taiwan males and smokers. Anticancer Res 34: 7001-7005, 2014. PMID: 25503126.

13 Hsia TC, Tsai CW, Liang SJ, Chang WS, Lin LY, Chen WC, Tu $\mathrm{CY}$, Tsai $\mathrm{CH}$ and Bau DT: Effects of ataxia telangiectasia mutated (ATM) genotypes and smoking habits on lung cancer risk in Taiwan. Anticancer Res 33: 4067-4071, 2013. PMID: 24023351.

14 Chen X, Lu H, Zhao M, Tashiro K, Cassis LA and Daugherty A: Contributions of leukocyte angiotensin-converting enzyme to development of atherosclerosis. Arterioscler Thromb Vasc Biol 33: 2075-2080, 2013. PMID: 23846498. DOI: 10.1161/ ATVBAHA.113.301777

15 Liu CJ, Hsia TC, Tsai RY, Sun SS, Wang CH, Lin CC, Tsai CW, Huang CY, Hsu CM and Bau DT: The joint effect of hOGG1 single nucleotide polymorphism and smoking habit on lung cancer in Taiwan. Anticancer Res 30: 4141-4145, 2010. PMID: 21036733.

16 Liu CJ, Hsia TC, Wang RF, Tsai CW, Chu CC, Hang LW, Wang $\mathrm{CH}$, Lee HZ, Tsai RY and Bau DT: Interaction of cyclooxygenase 2 genotype and smoking habit in Taiwanese lung cancer patients. Anticancer Res 30: 1195-1199, 2010. PMID: 20530427.

17 Govindan R: Lung cancer in never smokers: a new hot area of research. Lancet Oncol 11: 304-305, 2010. PMID: 20304702. DOI: $10.1016 / \mathrm{S} 1470-2045(10) 70057-7$

18 Liu YL, Xu Y, Li F, Chen H and Guo SL: CYP2A6 deletion polymorphism is associated with decreased susceptibility of lung cancer in Asian smokers: a meta-analysis. Tumour Biol 34: 26512657, 2013. PMID: 23649654. DOI: 10.1007/s13277-013-0815-y

19 Lo YL, Hsiao CF, Jou YS, Chang GC, Tsai YH, Su WC, Chen KY, Chen YM, Huang MS, Hsieh WS, Chen CJ and Hsiung CA: Polymorphisms of MLH1 and MSH2 genes and the risk of lung cancer among never smokers. Lung Cancer 72: 280-286, 2011. PMID: 21093954. DOI: 10.1016/j.lungcan.2010.10.009

$20 \mathrm{Wu}$ X, Wang L, Ye Y, Aakre JA, Pu X, Chang GC, Yang PC, Roth JA, Marks RS, Lippman SM, Chang JY, Lu C, Deschamps C, Su WC, Wang WC, Huang MS, Chang DW, Li Y, Pankratz VS, Minna JD, Hong WK, Hildebrandt MA, Hsiung CA and Yang P: Genome-wide association study of genetic predictors of overall survival for non-small cell lung cancer in never smokers. Cancer Res 73: 4028-4038, 2013. PMID: 23704207. DOI: 10.1158/0008-5472.CAN-12-4033
21 Center DM and Cruikshank W: Modulation of lymphocyte migration by human lymphokines. I. Identification and characterization of chemoattractant activity for lymphocytes from mitogen-stimulated mononuclear cells. J Immunol 128 : 2563-2568, 1982. PMID: 7042840.

22 Baier M, Bannert N, Werner A, Lang K and Kurth R: Molecular cloning, sequence, expression, and processing of the interleukin 16 precursor. Proc Natl Acad Sci USA 94: 5273-5277, 1997. PMID: 9144227. DOI: 10.1073/pnas.94.10.5273

23 Drwinga HL, Toji LH, Kim CH, Greene AE and Mulivor RA: NIGMS human/rodent somatic cell hybrid mapping panels 1 and 2. Genomics 16: 311-314, 1993. PMID: 8314568. DOI: 10.1006/geno.1993.1190

24 Zhang Y, Center DM, Wu DM, Cruikshank WW, Yuan J, Andrews DW and Kornfeld H: Processing and activation of prointerleukin-16 by caspase-3. J Biol Chem 273: 1144-1149, 1998. PMID: 9422780. DOI: $10.1074 / \mathrm{jbc} .273 .2 .1144$

25 Mathy NL, Scheuer W, Lanzendorfer M, Honold K, Ambrosius D, Norley $\mathrm{S}$ and Kurth R: Interleukin-16 stimulates the expression and production of pro-inflammatory cytokines by human monocytes. Immunology 100: 63-69, 2000. PMID: 10809960. DOI: 10.1046/j.1365-2567.2000.00997.x

26 Zheng Y, Cao KY, Ng SP, Chua DT, Sham JS, Kwong DL, Ng $\mathrm{MH}, \mathrm{Lu} \mathrm{L}$ and Zheng BJ: Complementary activation of peripheral natural killer cell immunity in nasopharyngeal carcinoma. Cancer Sci 97: 912-919, 2006. PMID: 16805822. DOI: $10.1111 / \mathrm{j} .1349-7006.2006 .00252 . x$

27 Kovacs E: The serum levels of IL-12 and IL-16 in cancer patients. Relation to the tumour stage and previous therapy. Biomed Pharmacother 55: 111-116, 2001. PMID: 11293814. DOI: $10.1016 / \mathrm{s} 0753-3322(00) 00023-8$

28 Liebrich M, Guo LH, Schluesener HJ, Schwab JM, Dietz K, Will $\mathrm{BE}$ and Meyermann R: Expression of interleukin-16 by tumorassociated macrophages/activated microglia in high-grade astrocytic brain tumors. Arch Immunol Ther Exp (Warsz) 55: 4147, 2007. PMID: 17221335. DOI: 10.1007/s00005-007-0003-0

29 Koike M, Sekigawa I, Okada M, Matsumoto M, Iida N, Hashimoto $\mathrm{H}$ and Oshimi $\mathrm{K}$ : Relationship between $\mathrm{CD} 4(+) / \mathrm{CD} 8(+) \mathrm{T}$ cell ratio and $\mathrm{T}$ cell activation in multiple myeloma: reference to IL-16. Leuk Res 26: 705-711, 2002. PMID: 12191564. DOI: 10.1016/s0145-2126(01)00192-8

30 Alexandrakis MG, Passam FH, Kyriakou DS, Christophoridou AV, Perisinakis K, Hatzivasili A, Foudoulakis A and Castanas E: Serum level of interleukin-16 in multiple myeloma patients and its relationship to disease activity. Am J Hematol 75: 101-106, 2004. PMID: 14755377. DOI: 10.1002/ajh.10444

31 Passam FH, Sfiridaki A, Pappa C, Kyriakou D, Petreli E, Roussou PA and Alexandrakis MG: Angiogenesis-related growth factors and cytokines in the serum of patients with B nonHodgkin lymphoma; relation to clinical features and response to treatment. Int J Lab Hematol 30: 17-25, 2008. PMID: 18190463. DOI: $10.1111 / \mathrm{j} .1365-2257.2006 .00890 . \mathrm{x}$

32 Blaschke V, Reich K, Middel P, Letschert M, Sachse F, Harwix $\mathrm{S}$ and Neumann C: Expression of the CD4+ cell-specific chemoattractant interleukin-16 in mycosis fungoides. J Invest Dermatol 113: 658-663, 1999. PMID: 10504456. DOI: 10.1046/j.1523-1747.1999.00717.x

33 Gao LB, Rao L, Wang YY, Liang WB, Li C, Xue H, Zhou B, Sun H, Li Y, Lv ML, Du XJ and Zhang L: The association of interleukin-16 polymorphisms with IL-16 serum levels and risk 
of colorectal and gastric cancer. Carcinogenesis 30: 295-299, 2009. PMID: 19073878. DOI: 10.1093/carcin/bgn281

34 Thomas G, Jacobs KB, Yeager M, Kraft P, Wacholder S, Orr N, Yu K, Chatterjee N, Welch R, Hutchinson A, Crenshaw A, Cancel-Tassin G, Staats BJ, Wang Z, Gonzalez-Bosquet J, Fang J, Deng X, Berndt SI, Calle EE, Feigelson HS, Thun MJ, Rodriguez C, Albanes D, Virtamo J, Weinstein S, Schumacher FR, Giovannucci E, Willett WC, Cussenot O, Valeri A, Andriole GL, Crawford ED, Tucker M, Gerhard DS, Fraumeni JF Jr., Hoover R, Hayes RB, Hunter DJ and Chanock SJ: Multiple loci identified in a genome-wide association study of prostate cancer. Nat Genet 40: 310-315, 2008. PMID: 18264096. DOI: 10.1038/ ng.91

35 Chen GL, Shen TC, Chang WS, Tsai CW, Li HT, Chuang CL, Lai YL, Yueh TC, Hsia TC, Wang SC and Bau DT: The contribution of MMP-7 promoter polymorphisms to Taiwan lung cancer susceptibility. Anticancer Res 38: 5671-5677, 2018. PMID: 30275186. DOI: 10.21873/anticanres.12903

36 Tsai CB, Hsia NY, Wang YC, Wang ZH, Chin YT, Huang TL, Yu CC, Chang WS, Tsai CW, Yin MC and Bau DT: The significant association of MMP-1 genotypes with Taiwan pterygium. Anticancer Res 40: 703-707, 2020. PMID: 32014911. DOI: 10.21873 /anticanres.14000

37 Hsu SW, Gong CL, Hsu HM, Chao CC, Wang YC, Chang WS, Tsai YT, Shih LC, Tsai CW and Bau DT: Contribution of matrix metalloproteinase-2 promoter genotypes to nasopharyngeal cancer susceptibility and metastasis in Taiwan. Cancer Genomics Proteomics 16: 287-292, 2019. PMID: 31243109. DOI: $10.21873 / \operatorname{cgp} .20133$

38 Yueh TC, Hung YW, Shih TC, Wu CN, Wang SC, Lai YL, Hsu SW, Wu MH, Fu CK, Wang YC, Ke TW, Chang WS, Tsai CW and Bau DT: Contribution of murine double minute 2 genotypes to colorectal cancer risk in Taiwan. Cancer Genomics Proteomics 15: 405-411, 2018. PMID: 30194081. DOI: 10.21873/cgp.20099

39 Fu CK, Chien YC, Chuang HY, Wang YC, Hwang JJ, Yang MD, Yu CC, Chen JC, Chang WS, Bau DT and Tsai CW: The association of MMP7 promoter polymorphisms with gastric cancer. Anticancer Res 40: 695-702, 2020. PMID: 32014910. DOI: 10.21873 /anticanres.13999

40 Li S, Deng Y, Chen ZP, Huang S, Liao XC, Lin LW, Li H, Peng T, Qin X and Zhao JM: Genetic polymorphism of interleukin-16 influences susceptibility to HBV-related hepatocellular carcinoma in a Chinese population. Infect Genet Evol 11: 20832088, 2011. PMID: 22019522. DOI: 10.1016/j.meegid. 2011.09 .025

41 Gao LB, Liang WB, Xue H, Rao L, Pan XM, Lv ML, Bai P, Fang WL, Liu J, Liao M and Zhang L: Genetic polymorphism of interleukin-16 and risk of nasopharyngeal carcinoma. Clin Chim Acta 409: 132-135, 2009. PMID: 19758567. DOI: 10.1016/j.cca.2009.09.017
42 Wang Z, Xu Y and Zhu S: Interleukin-16 rs4778889 polymorphism contributes to the development of renal cell cancer in a Chinese population. Int J Clin Exp Pathol 8: 1522815233, 2015. PMID: 26823871.

43 Zhou T, Li H, Xie WJ, Zhong Z, Zhong $\mathrm{H}$ and Lin ZJ: Association of methylenetetrahydrofolate reductase, vitamin D receptor, and interleukin-16 gene polymorphisms with renal cell carcinoma risk. Technol Cancer Res Treat 18: 1533033819859413, 2019. PMID: 31242814. DOI: 10.1177/ 1533033819859413

44 Kovacs E: The serum levels of IL-12 and IL-16 in cancer patients. Relation to the tumour stage and previous therapy. Biomed Pharmacother 55: 111-116, 2001. PMID: 11293814. DOI: $10.1016 / \mathrm{s} 0753-3322(00) 00023-8$

45 Yellapa A, Bitterman P, Sharma S, Guirguis AS, Bahr JM, Basu $\mathrm{S}$, Abramowicz JS and Barua A: Interleukin 16 expression changes in association with ovarian malignant transformation. Am J Obstet Gynecol 210: 272 e271-210, 2014. PMID: 24380743. DOI: 10.1016/j.ajog.2013.12.041

46 Gao LB, Rao L, Wang YY, Liang WB, Li C, Xue H, Zhou B, Sun H, Li Y, Lv ML, Du XJ and Zhang L: The association of interleukin-16 polymorphisms with IL-16 serum levels and risk of colorectal and gastric cancer. Carcinogenesis 30: 295-299, 2009. PMID: 19073878. DOI: 10.1093/carcin/bgn281

47 Batai K, Shah E, Murphy AB, Newsome J, Ruden M, Ahaghotu $\mathrm{C}$ and Kittles RA: Fine-mapping of IL16 gene and prostate cancer risk in African Americans. Cancer Epidemiol Biomarkers Prev 21: 2059-2068, 2012. PMID: 22923025. DOI: 10.1158/ 1055-9965.EPI-12-0707

48 Zhu J, Qin C, Yan F, Wang M, Ding Q, Zhang Z and Yin C: IL16 polymorphism and risk of renal cell carcinoma: association in a Chinese population. Int J Urol 17: 700-707, 2010. PMID: 20529140. DOI: 10.1111/j.1442-2042.2010.02559.x

49 Donati K, Sepult C, Rocks N, Blacher S, Gerard C, Noel A and Cataldo D: Neutrophil-derived interleukin 16 in premetastatic lungs promotes breast tumor cell seeding. Cancer Growth Metastasis 10: 1179064417738513, 2017. PMID: 29123422. DOI: $10.1177 / 1179064417738513$

50 Perez-Ramirez C, Canadas-Garre M, Alnatsha A, Molina MA, Robles AI, Villar E, Delgado JR, Faus-Dader MJ and CallejaHernandez MA: Interleukins as new prognostic genetic biomarkers in non-small cell lung cancer. Surg Oncol 26: 278-285, 2017. PMID: 28807247. DOI: 10.1016/j.suronc.2017.05.004

Received February 7, 2020

Revised March 2, 2020

Accepted March 6, 2020 